\title{
Spontán suprachorioidealis vérzés okozta vakság véralvadásgátló kezelésben részesült időskori makuladegenerációs betegeken
}

\author{
Ecsedy Mónika dr. - Csákány Béla dr. - Kovács Illés dr. \\ Resch Miklós dr. - Nagy Zoltán Zsolt dr. - Récsán Zsuzsa dr. \\ Semmelweis Egyetem, Általános Orvostudományi Kar, Szemészeti Klinika, Budapest
}

\begin{abstract}
Dolgozatunkban a spontán érhártyavérzés miatt megvakult időskori makuladegenerációs betegeink kórtörténetét ismertetjük. Klinikánkon retrospektív vizsgálat keretében 2016 januárja és 2017 áprilisa között 6 időskori makuladegenerációs beteg 7 szemén észleltünk spontán érhártyabevérzést. Ismertetjük az általános és szemészeti rizikófaktorokat, az alkalmazott kezelési eljárásokat és a végső kimenetelt. Szív- és érrendszeri betegség miatt minden betegünk részesült valamilyen típusú szisztémás antikoaguláns kezelésben. Egy betegnél az általános kivizsgálás a haemostasist jelentősen befolyásoló hematológiai háttérbetegséget (krónikus lymphoid leukaemia) igazolt. Nedves típusú időskori makuladegeneráció miatt korábban minden szem kapott intravitrealis anti-VEGF-kezelést. A leggyakoribb szemészeti szövődményként konzervatív terápiával uralhatatlan másodlagos zöld hályog kialakulását észleltük. Használható látóélességet egyik szemnél sem tudtunk elérni. Szisztémás antikoaguláns kezelésben részesült, nedves típusú időskori makuladegenerációs betegeknél jelentősen megnő a vakságot okozó érhártyabevérzések kockázata. Elkerülésük érdekében a vérhígító beállításakor, és krónikus szedés folyamán is, rendszeres szemfenékvizsgálat, illetve a szemész és belgyógyász/kardiológus szoros együttmúködése volna szükséges.
\end{abstract}

Orv Hetil. 2018; 159(24): 985-990.

Kulcsszavak: érhártyabevérzés, időskori makuladegeneráció, antikoaguláns kezelés

\section{Blinding spontaneous suprachoroidal haemorrhage in anticoagulant taking wet-AMD patients}

We present cases of blinding spontaneous suprachoroidal haemorrhage in anticoagulant taking wet-AMD patients. A retrospective study has been performed to present the clinical course, management and final outcome of spontaneous suprachoroidal haemorrhage in 7 eyes of six age-related macular degeneration patients seen in our clinic from January 2016 to April 2017. All patients were on chronic oral anticoagulant therapy because of cardiovascular disorder. In one patient, haematological disorder was also present modifying significantly the haemostasis. All eyes received prior anti-VEGF treatment for exsudative AMD. Acute angle closure glaucoma - with no response to topical and oral IOP lowering therapy - was the most frequent ocular complication in our cases. The final visual prognosis was usually very poor. The risk of spontaneous suprachoroidal haemorrhage is increased in wet-AMD patients who are on anticoagulant therapy. To prevent this blinding condition, a stronger communication between ophthalmologists and cardiologists would be beneficial, with an ophthalmological check-up in this group of patients before and during the use of anticoagulants.

Keywords: suprachoroidal haemorrhage, age-related macular degeneration, anticoagulant therapy

Ecsedy M, Csákány B, Kovács I, Resch M, Nagy ZZs, Récsán Zs. [Blinding spontaneous suprachoroidal haemorrhage in anticoagulant taking wet-AMD patients]. Orv Hetil. 2018, 159(24): 985-990.

(Beérkezett: 2017. október 16.; elfogadva: 2017. november 13.) 


\section{Rövidítések}

$\mathrm{AMD}=($ age-related macular degeneration $)$ időskori makuladegeneráció; $\mathrm{CPC}=$ (cyclophotocoagulation) ciklofotokoaguláció; $\mathrm{COPD}=($ chronic obstructive pulmonary disease $)$ krónikus obstruktív tüdőbetegség; INR = (international normal ratio) nemzetközi normalizált ráta; $\mathrm{IOP}=$ (intraocular pressure) intraocularis nyomás; LMWH = (low-molecular-weight heparin) kis molekulatömegü heparin; PPV = pars plana vitrectomia; TIA $=$ (transient ischemic attack) átmeneti ischaemiás roham; VEGF = (vascular endothelial growth factor $)$ vascularis endothelialis növekedési faktor

Az időskori makuladegeneráció (angol elnevezés szerint age-related macular degeneration, röviden AMD) a látóhártya központi részének (macula lutea) előrehaladó sorvadása, mely a 75 év feletti populáció $2 / 3$-át érinti, és 10-15\%-ukban az érhártyából induló érújdonképződés kialakulásához vezet $[1,2]$. Az AMD kezelése jelenti napjainkban a szemészet egyik legnagyobb problémáját, ugyanis az iparosodott országokban ez a szembetegség a jogi értelemben vett vakság (látásélesség $<0,1$ ) leggyakoribb oka $[1,2]$. Becslések szerint Magyarországon 300500 ezerre tehetô a betegek száma [3]. Az utóbbi évtizedben elterjedt anti-VEGF-kezeléseknek köszönhetően a nedves típusú AMD lefolyása lassítható, a centrális látóélesség megőrzésével a beteg életminősége, önellátó képessége is megőrizhető vagy évekre stabilizálható.

A spontán roncsoló érhártyabevérzés ritka kórkép, kialakulása azonban az esetek legnagyobb részében visszafordíthatatlan látásvesztést és konzervatív terápiával uralhatatlan másodlagos zöld hályog kialakulását vonja maga után [4-7]. A nedves típusú AMD önmagában fokozott rizikófaktorként ismert a betegség kialakulásában, mivel a chorioidealis érújdonképződéses membránok érhálózata rupturára hajlamos, ideghártya alatti bevérzéseket okozva [8]. Szintén fokozott kockázatot jelenthet, hogy az AMD-s betegek általában egyéb krónikus anyagcsereés szív-ér rendszeri betegségekben is szenvednek, melyek miatt gyakran állítják őket tartós antikoaguláns vagy thrombocytaaggregáció-gátló kezelésre. Ezen gyógyszerek szedése pedig az irodalomban önálló prediszponáló tényezőként ismert, AMD-ben nem szenvedő betegek esetében is, a suprachorioidealis vérzések kialakulásában [9-13].

Tanulmányunkban spontán érhártyavérzés miatt megvakult időskori makuladegenerációs betegeink kórtörténetét ismertetjük, a két betegség egyidejü fennállásának jobb megértése, illetve a vakság esetleges megelőzési lehetőségeinek megtalálása céljából.

\section{Esetismertetések}

\section{Az elsö eset}

A 76 éves nőbeteget 2016. februárban háziorvosi ügyelet irányította klinikánkra 3 napja kezdődött, bal oldali látásromlás és lüktető fájdalom miatt. Réslámpás és ultra- hangos vizsgálat a bal szemen magas chorioidealeválást és üvegtesti vérzést igazolt, az elülső csarnok hiányával és magas szemnyomással (IOP $52 \mathrm{Hgmm}$ ). Szemészeti anamnézisében 2011 óta ismert kétoldali nedves AMD, mely miatt mindkét szem 2 alkalommal anti-VEGF (ranibizumab)-kezelésben részesült, a bal szemen utoljára 2012 novemberében (akkor a bal szem látólélessége: $0,1)$. Általános kórtörténetében 20 éve kezelt hypertonia és 2-es típusú diabetes (2010 óta inzulinkezeléssel kiegészítve) szerepelt. 2004-ben aortabillentyü-elégtelenség miatt billentyúcsere történt, azóta acenokumarolkezelést kapott (látásvesztéskor mért INR: 4,28). Mivel szemnyomását konzervatív terápiával csökkenteni nem tudtuk, és a bal szem látóélessége fényérzés nélküli volt, üvegtesti mútétet nem kíséreltünk meg, hanem a csarnokvíztermelés csökkentésére diódalézeres ciklofotokoagulációt $(\mathrm{CPC})$ végeztünk. A kezelés hatására fájdalma megszúnt, szemnyomása csökkent, de a szem fényérzés nélküli maradt.

\section{A második eset}

A 77 éves nőbeteg 2016. december 9-én jelentkezett klinikánkon a jobb szemén észlelt hirtelen látásvesztés és fájdalom miatt. Felvételekor a jobb szemen sekélyebb csarnokot és a vörös visszfény teljes hiányát észleltük retinalis képletek lencse mögötti sejthető előboltosulásával, aminek hátterében az ultrahangos vizsgálat magas vérzéses chorioidealeválást igazolt $(1 / A$ és $1 / B$ ábra). Szemnyomása a felvételkor $61 \mathrm{Hgmm}$ volt. Szemészeti anamnézisében 2013 óta ismert kétoldali nedves AMD szerepelt, mely miatt mindkét szem több alkalommal anti-VEGF (10 ranibizumab, 7 aflibercept)-kezelésben részesült, a jobb szemen utoljára 2015 novemberében (akkor a jobb szem látóélessége: 0,1). Általános kórtörténetéból kezelt hypertonia és pitvarfibrilláció miatt krónikus warfarinkezelés ismert. Felvételekor az INR-érték: 7,65; mindkét alsó végtagon multiplex börbevérzések voltak láthatók. Konzervatív úton szemnyomását nem tudtuk csökkenteni, ezért 2016. december 23-án CPC-t végeztünk, majd ennek sikertelensége miatt december 29-én ciklokriopexiát. Ezt követően a beteg fájdalma megszúnt. A követés során az ultrahanggal 2017 márciusáig a subchorioidealis vérzés szervülését észleltük, elfolyósodás nem következett be, így a vérzés mútéti úton történő lebocsátását nem kíséreltük meg $(1 / C a ́ b r a)$. Közben a jobb szem fényérzés nélkülivé vált.

\section{A harmadik eset}

A 77 éves férfi beteg 2016. december 22-én egyetlen látó, bal szemén hirtelen kialakult látásromlás és fájdalom miatt jelentkezett klinikánkon. Felvételekor a bal szemen a vörös visszfény teljes hiányát észleltük, aminek hátterében az ultrahangos vizsgálat magas vérzéses chorioidealeválást igazolt. Szemészeti anamnézisében 2011 


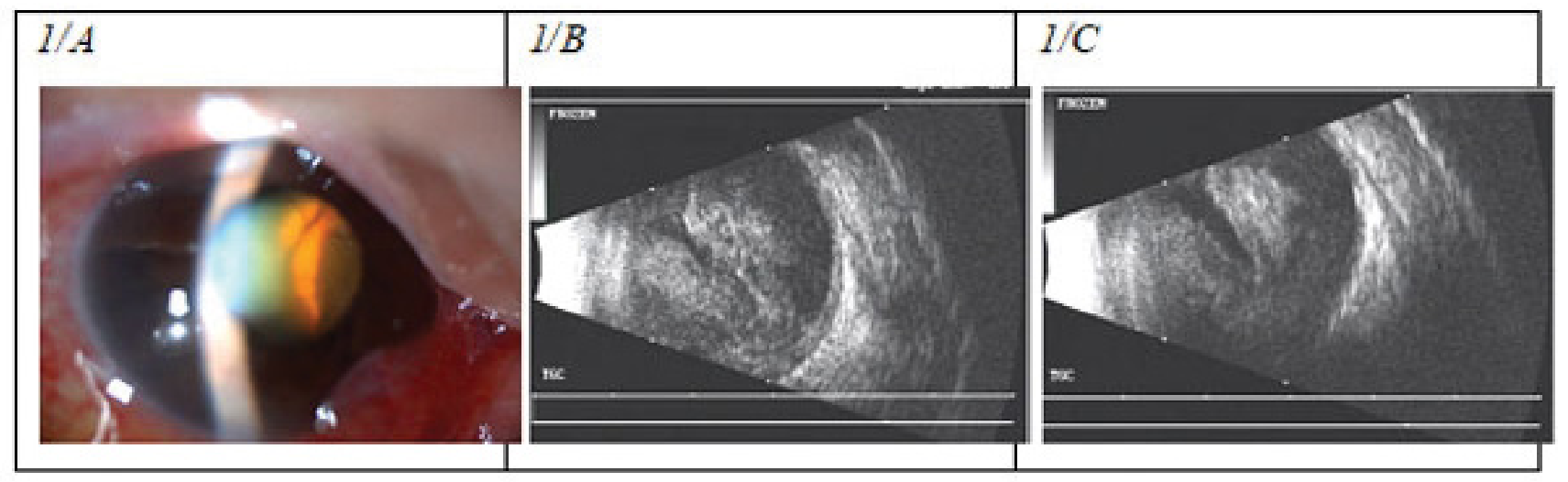

1. ábra
1/A: Réslámpás fotó az első megjelenéskor: sekély csarnok és a pupillát átvilágítva a lencse mögött hólyagszerúen előboltosuló retina látszik vörös visszfény hiányával
1/B: B-módú ultrahangvizsgálat a tünetek jelentkezésekor. Kifejezetten magas chorioidealeválás (convex lefutású immobilis membránok) mögött nagy mennyiségú vér
1/C: 4 hét múlva ultrahanggal a chorioidealeválás enyhe csökkenése látható, a bulbus belsejének nagy részét most is a chorioidea mögötti vér foglal- ja el (2. eset)

óta anti-VEGF-injekciókkal kezelt ismert kétoldali nedves AMD szerepelt. Jobb szemén 2 bevacizumabinjekciót kapott, táblavisusát nem sikerült megőrizni; 2014 áprilisában üvegtesti vérzés alakult ki ezen a szemén, ami miatt szürkehályog-mütét és vitrectomia történt. Látóélessége azonban a beavatkozásokat követően sem javult. Bal szemébe 6 alkalommal ranibizumab, majd 3 alkalommal afliberceptkezelést kapott, utoljára 2015 novemberében (látóélesség: 0,125). Kórelőzményében pitvarfibrilláció, duodenalis ulcus miatt gastrointestinalis vérzés, kezelt hypertonia, GOLD II. stádiumú COPD, thrombocytopenia és bradycardia miatt pacemakerbeültetés szerepelt. A pacemaker beültetése óta klopidogrélkezelést kapott. 2015 decemberében elesés miatti hospitalizáció során derült ki krónikus lymphoid leukaemiája, ekkor vérhígító kezelését leállították. 2016 szeptemberében, mivel ultrahangos vizsgálattal subretinalis vér elfolyósodása volt sejthető, hematológiai állapota pedig szteroid- és MabThera-kezelésre kielégítően rendeződött, a bal szemen szürkehályog-mütétet és sclera punctióval kombinált vitrectomiát végeztünk. A mütétet követően a retina az alapjára visszafeküdt, de felszínén súlyos degeneratív elváltozások váltak láthatóvá; a beteg látóélessége a kézmozgáslátás maradt.

\section{A negyedik eset}

A 79 éves férfi beteg 2016. május 17-én egyetlen látó, jobb szemén hirtelen kialakult teljes látásvesztés miatt jelentkezett. Felvételekor a bal szemen a vörös visszfény teljes hiányát észleltük, aminek hátterében az ultrahangos vizsgálat magas vérzéses chorioidealeválást igazolt. A bal szemen nedves AMD miatt 2006-ban fotodinámiás terápiában részesült, majd látóélessége fokozatosan fél méter ujjolvasásig romlott. 2011-ben a jobb szemén is jelentkezett a betegség, melyre azóta ismételt anti-IKOkezeléseket kapott ( 26 bevacizumab- és 7 afliberceptin- jekció). Utolsó kezelése 2016 áprilisában történt (látóélesség: 0,16). Általános anamnézisében 2-es típusú diabetes, hypertonia, colontumor miatt mútét és kemoterápia, és 2015-ben átmeneti ischaemiás roham (TIA) szerepelt. 2016 márciusában pitvarfibrillációt észleltek, és a beteget acenokumarolterápiára állították. 2016 májusában LMWH mellett üvegtesti mútétet kíséreltünk meg sclera punctióval, de a mütétet követően ismételt rávérzés és üvegtesti vérzés alakult ki jelentős szemnyomás-emelkedéssel. 2016 júniusában ismételt üvegtesti mútétet hajtottunk végre, a korai posztoperatív időszakban csarnokbevérzés alakult ki, melyet kiöblítettünk. Ezt követően a retina az alapjára visszafeküdt, de felszínén súlyos degeneratív elváltozások váltak láthatóvá, a beteg látóélessége a fénysejtés maradt.

\section{Az ötödik eset}

A 79 éves férfi beteg 2016 márciusában jelentkezett először klinikánkon a jobb szemén észlelt hirtelen látásromlás és fájdalom miatt. Ultrahangos vizsgálattal panaszai hátterében magas vérzéses érhártyaleválást találtunk. 2016 novemberében a bal szemen is először részleges, majd 2-3 nap alatt teljessé váló vérzéses chorioidealeválás alakult ki szemnyomás-emelkedés nélkül. Szemészeti anamnézisében a jobb szemen 2009 és 2011 között nedves AMD miatt többszörös bevacizumabkezelés, a bal szemen pedig 2012-ben 1 ranibizumabkezelés szerepelt. Az utolsó kezelés a bal szemen 2011-ben, a jobbon 2012 márciusában történt, ekkor mindkét szem látóélessége 0,1 volt. Általános kórelőzményében pacemakerbeültetés, pitvarfibrilláció, akut myocardialis infarctus (háromér-betegség), hypertonia, ischaemiás stroke (2013. december), hyperuricaemia, hyperlipidaemia, suprarenalis hasiaorta-aneurizma, valamint krónikus vénás keringési elégtelenség szerepelt. Antikoagulánsként Aspirin Protectet és acenokumarolt szedett. A 2016-os érhártyavér- 
zés idején 2,34-es INR-t mértünk. Jobb szemén konzervatív úton a szemnyomását nem tudtuk csökkenteni, ezért 2016 márciusában CPC-t végeztünk. A beavatkozás után a szemgolyó hypotonná vált, fokozatos zsugorodásnak indult, és fényérzését is elvesztette. A bal szemen kialakuló és fokozódó érhártyabevérzés után antikoaguláns kezelését kardiológiai konszenzussal rivaroxaban (Xarelto)-kezelésre állítottuk át. Ezután az ultrahangos követés során a vérzés szervülése, majd spontán felszívódása volt megfigyelhető, de a fényérzés ezen a szemen is elveszett.

\section{$A$ batodik eset}

A 80 éves férfi beteg jobb oldali hirtelen látásvesztés miatt 2016 decemberében, akut myocardialis infarctus miatt végzett koronarográfia után 2 héttel jelentkezett klinikánkon. Felvételekor jobb szemén a vörös visszfény teljes hiányát észleltük, aminek hátterében az ultrahangos vizsgálat magas vérzéses chorioidealeválást és üvegtesti vérzést igazolt. Szemészeti anamnézisében a jobb szemen 2015 novembere óta ismert magas pigmenthámleválással, majd spontán pigmenthámrupturával járó nedves AMD szerepelt. Mivel a ruptura extrafovealisan alakult ki, a jobb szemen 3 alkalommal anti-VEGF (ranibizumab)-kezelésben részesült, utoljára 2016 szeptemberében (akkor a jobb szem látóélessége: 0,05). A beteg általános kórtöténetében a fentebb említett kardiológiai beavatkozást követően klopidogrél (Thrombex) és Aspirin Protect beállítása történt (közvetlenül a vérzéses szemészeti esemény előtt). 2017 januárjában üvegtesti mútétet terveztünk, de a páciens kardiológiai állapota rosszabbodott, így a beavatkozást nem tudtuk elvégezni. Ezután még 2 alkalommal rekoronarográfiát és stentbeültetést végeztek. Mitralis regurgitatio jelenlétét is észlelték, ezért szívsebészeti beavatkozást is tervbe vettek. Közben a jobb szem látóélessége fényérzés nélkülivé vált.

\section{Eredmények}

Betegeink adatait az 1. táblázatban foglaltuk össze.

Két nő- és 4 férfi betegünk mindegyike 70 év feletti életkorú volt, és anamnézisükben súlyos cardiovascularis (hypertonia 6/6 beteg, infarctus 2/6 beteg, stroke 2/6 beteg, ritmuszavar $4 / 6$ betegnél pitvarfibrilláció) és anyagcsere-betegségek (diabetes $2 / 6$ beteg, hyperlipidaemia $3 / 6$ beteg, hyperuricaemia $1 / 6$ beteg) szerepeltek. Minden betegünk valamilyen típusú szisztémás antikoaguláns kezelésben részesült, 2 beteg egyszerre 2 különböző támadáspontú vérhígító gyógyszert is szedett (5. és 6. eset). Két betegnél az INR-érték jelentősen meghaladta a kívánt terápiás tartományt. Egy beteg esetében az általános kivizsgálás haemostasist jelentősen befolyásoló hematológiai háttérbetegséget igazolt (krónikus lymphoid leukaemia). Egy betegünknél pedig invazív kardiológiai beavatkozást követően alakult ki az érhártyabevérzés.

Minden szem kapott korábban intravitrealis antiVEGF-terápiát nedves típusú időskori makuladegeneráció miatt. Az utolsó anti-VEGF-kezelés óta eltelt idő 1 hónap és 4 év között változott. Az érbelhártya-bevérzés hirtelen látásromlásként jelentkezett, ami a legjobban szemészeti ultrahangos vizsgálat B-scanje segítségével volt detektálható. A leggyakoribb szemészeti szövődményként (4/7 szem) konzervatív terápiával uralhatatlan másodlagos zöld hályog kialakulását észleltük. Üvegtesti mütétet 2 esetben kíséreltünk meg. Használható látóélességet egyik szem esetében sem tudtunk elérni.

1. táblázat |A betegek adatainak összefoglalása

\begin{tabular}{|c|c|c|c|c|c|c|c|}
\hline Szemek & Életkor & Nem & Általános betegségek & Antikoaguláns kezelés & Anti-VEGF-kezelés & $\begin{array}{l}\text { Másodlagos } \\
\text { zöld hályog }\end{array}$ & $\begin{array}{l}\text { Szemészeti } \\
\text { kezelés }\end{array}$ \\
\hline 1 & 76 & Nő & $\begin{array}{l}\text { Hypertonia, 2-es típusú } \\
\text { diabetes, aortabillentyű-csere }\end{array}$ & $\begin{array}{l}\text { Acenokumarol } \\
(\text { INR 4,28) }\end{array}$ & 2 ranibizumab & + & $\mathrm{CPC}$ \\
\hline 2 & 77 & Nő & Hypertonia, pitvarfibrilláció & $\begin{array}{l}\text { Warfarin } \\
(\text { INR } 7,65)\end{array}$ & $\begin{array}{l}10 \text { ranibizumab } \\
7 \text { aflibercept }\end{array}$ & + & $\begin{array}{l}\text { CPC, } \\
\text { ciklokriopexia }\end{array}$ \\
\hline 3 & 77 & Férfi & $\begin{array}{l}\text { Hypertonia, pitvarfibrilláció, } \\
\text { pacemaker, } \\
\text { lymphoid leukaemia }\end{array}$ & Klopidogrél & $\begin{array}{l}6 \text { ranibizumab } \\
3 \text { aflibercept }\end{array}$ & - & $\begin{array}{l}\mathrm{PPV}+\text { sclera } \\
\text { punctio }\end{array}$ \\
\hline 4 & 79 & Férfi & $\begin{array}{l}\text { Hypertonia, } \\
\text { pitvarfibrilláció, } \\
\text { TIA }\end{array}$ & Acenokumarol & $\begin{array}{l}26 \text { bevacizumab } \\
7 \text { aflibercept }\end{array}$ & + & $\begin{array}{l}\mathrm{PPV}+\text { sclera } \\
\text { punctio }\end{array}$ \\
\hline 5 & 79 & Férfi & $\begin{array}{l}\text { Hypertonia, stroke, } \\
\text { pitvarfibrilláció, } \\
\text { pacemaker, }\end{array}$ & $\begin{array}{l}\text { Acenokumarol } \\
\text { Aspirin Protect } \\
(\text { INR 2,34) }\end{array}$ & 21 bevacizumab & + & $\mathrm{CPC}$ \\
\hline 6 & 79 & Férfi & $\begin{array}{l}\text { Hypertonia, stroke, } \\
\text { pitvarfibrilláció, } \\
\text { pacemaker }\end{array}$ & $\begin{array}{l}\text { Acenokumarol } \\
\text { Aspirin Protect } \\
(\text { INR 2,34) }\end{array}$ & $\begin{array}{l}15 \text { bevacizumab } \\
1 \text { ranibizumab }\end{array}$ & - & - \\
\hline 7 & 80 & Férfi & $\begin{array}{l}\text { Myocardialis infarctus miatt } \\
\text { koronarográfia }\end{array}$ & $\begin{array}{l}\text { Klopidogrél } \\
\text { Aspirin Protect }\end{array}$ & 3 ranibizumab & - & - \\
\hline
\end{tabular}




\section{Megbeszélés}

A spontán roncsoló érhártyabevérzés ritka, az esetek túlnyomó részében vakságot okozó kórkép [6]. Kialakulásában mind általános, mind szemészeti rizikófaktorok szerepet játszhatnak [9-13]. Az előzőek közül a legfontosabbak - az irodalom szerint - a chorioidealis és a hátsó ciliaris artériák törékenységét okozó általános betegségek, mint az atherosclerosis, az előrehaladott életkor, a hypertonia és a diabetes. A szemészeti rizikótényezők közül a nagyfokú rövidlátás és az időskori makuladegeneráció szerepel a korábbi közlésekben $[10,12]$. A harmadik említett csoport pedig a haemostasist befolyásoló kórképek és gyógyszerek (különböző antikoagulánsok) alkalmazása. Eseteink mind a három csoportban az említett prediszponáló tényezőkkel egyidejűleg rendelkeztek, hiszen mindegyikük 70 évnél idősebb volt, makuladegenerációban szenvedtek, illetve valamilyen antikoaguláns kezelésben részesültek $[8,13]$. Az anti-VEGFkezelés és a betegség kialakulása közötti kapcsolat ez idáig nem tisztázott az irodalomban.

A betegség vagy gyorsan progrediáló látótérkiesés, vagy hirtelen látásvesztés formájában jelentkezett. Diagnózisában nagyon hasznos képalkotó eszköznek bizonyult a szemészeti ultrahangvizsgálat (B-mód), mivel a réslámpás biomikroszkópia során általában a fundusképletek nem voltak identifikálhatók. Az ultrahangos vizsgálat a követés során is fontos szerepet játszott, hiszen segítséget nyújtott a suprachorioidealis térben felgyülemlett vér áramlási viszonyainak tisztázásában, segítve ezzel az esetleges sclerotomia és vérlebocsátás időzítésének meghatározását.

A klinikai kép a másodlagos zöld hályoggal járó esetekben jellegzetes elülsőszegment-elváltozásokkal járt, mint a rendkívül sekély csarnok, akár szaruhártya-írisz-, illetve szaruhártya-lencse-érintkezéssel, valamint a vörös visszfény részleges vagy teljes hiánya. A másodlagos zöld hályog - az irodalomhoz hasonlóan - betegeinknél is a leggyakoribb szövődményként jelentkezett (57,14\%, $4 / 7$ szem). Kialakulásának hátterében a lencse-írisz diaphragma suprachorioidealis vérzés miatti előretolódása és így a csarnokzug mechanikus elzáródása állhatott, melynek előfordulása az irodalom szerint 87,5\% [4-7]. Az akut glaucomás rohamra hasonlító klinikai kép ellenére itt sem a perifériás iridotomia, sem a pupillaszúkítők használata nem vezet eredményre, sőt ellenjavallt, mivel a lencse-írisz diaphragma további előrehelyeződését okozza. A beteg fájdalma egyes esetekben még a sugártest pusztító - csarnokvíztermelést csökkentő - eljárásokkal (ciklofotokoaguláció, ciklokriopexia) sem szüntethető meg, ilyenkor a szemgolyó belsejének vagy egészének eltávolítására is kényszerülhetünk [5-7]. A betegség prognózisa tehát a jelen kezelési lehetőségeink mellett rendkívül rossz [4-7].

Terápiás fegyvertárunkban még a sclerotomián át történő vérlebocsátás vagy ennek pars plana vitrectomiával és lensectomiával kombinált mütéte szerepelhet. Indiká- cióként a lencse-szaruhártya-érintkezést, a fokozódó corneaoedemát, illetve szemnyomás-emelkedést, valamint a szürke hályog kialakulását említik $[14,15]$. A mútét megfelelő időzítése azonban ez idáig nem tisztázott. A tünetek megjelenése után 7-25 nap közé teszik a műtét ideális idejét, mivel ennél korábban nagy a rávérzés veszélye, illetve a megszilárdult suprachorioidealis vér nem bocsátható le [14-16]. Későbbi esetekben pedig a vérzés szervülhet, valamint a magas szemnyomás hosszú idejű fennállása a látóideg végérvényes sorvadását okozhatja [16].

Az antikoaguláns kezelést illetóen, a warfarint tartják a leginkább veszélyesnek [9], illetve két különböző támadáspontú kezelés egyidejű alkalmazását. De heparin (hemodialízis kapcsán), illetve LMWH-kezelés mellett is közöltek már spontán érhártyabevérzéses esetet [17]. Ezenkívül fontos megjegyezni, hogy bár normál terápiás tartományban lévő INR mellett is közöltek eseteket, saját betegeinknél is előfordult a terápiás tartományt jelentősen meghaladó INR, vagyis nem kellő gyakorisággal ellenőrzött és nem megfelelóen beállított antikoaguláns kezelés. Az újabb antikoagulánsok (dabigatrán, rivaroxaban, apixaban, edoxaban) alkalmazása és az érhártyabevérzések kapcsolatát illetően Sun és mtsai közöltek egy nagyobb metaanalízist 2017-ben, mely szerint e szerek alkalmazása a warfarinhoz képest 1/5-ére csökkentheti a szemfenéki bevérzések kockázatát mind a pitvarfibrillációs, mind a vénás thromboembolisatio miatt antikoagulált betegek esetében [18]. A koponyaûri vérzéses esetekhez hasonlóan a szerzők azt gyanítják, hogy a csökkent rizikó hátterében egyrészt ezen új gyógyszerek szelektivitása állhat (egyetlen ponton avatkoznak be a véralvadási kaszkádba, szemben a warfarin többszörös támadáspontjával), másrészt nem gyakorolnak direkt hatást a VIIa véralvadási faktorra [19]. Nagy előnyük még a warfarinnal szemben, hogy nem igényelnek olyan gyakori monitorizálást, és használatuk során nem fenyeget a terápiás tartomány átlépése, ami szintén oka lehet a fokozott vérzésveszélynek [18].

Bár az AMD - mint a bevezetésben is említettük - a fejlett országokban a jogi értelemben vett vakság leggyakoribb oka [1-3], nem érinti a teljes látóteret. Így a betegek az arcfelismerési és olvasási képesség teljes elvesztése után is képesek maradnak megszokott környezetükben a tájékozódásra. Ezzel szemben az érhártyabevérzés bekövetkezése után látóterük nagy része vagy egésze elsötétedik, tájékozódási képességüket teljesen elveszíthetik. Főként igaz ez a kétszemes esetekre és azon betegekre, akiknek az egyetlen megmaradt látó szemén következik be a bevérzés, ami így jelentősen ronthatja életminőségüket, hangulati állapotukat és önellátó képességüket.

Eseteink ismertetésével arra szerettük volna felhívni a figyelmet, hogy a szisztémás antikoaguláns kezelésben részesülő nedves típusú időskori makuladegenerációs betegek esetében jelentősen megnő az érhártyabevérzések kockázata. Mivel a betegség az esetek túlnyomó többségében a látás végleges és teljes elvesztésével jár, a vak- 
ság elkerülése érdekében a kezelés beállításakor, és krónikus gyógyszerszedés folyamán is, rendszeres szemfenékvizsgálat, illetve a szemész és belgyógyász/kardiológus szoros együttmúködése lenne szükséges. Különösen igaz ez az egyik szemen már végstádiumú AMD miatt megvakult monoculus betegekre. A szemész és kardiológus szorosabb együttműködését javasolnánk, mind a beteg számára legmegfelelőbb antikoaguláns szer kiválasztására (a szemfenéki vérzés fokozott rizikója esetén újabb antikoagulánsok beállítása), mind a kívánt terápiás tartomány, mind pedig a monitorozási gyakoriság egyénre szabott meghatározására.

Anyagi támogatás: A közlemény megírása anyagi támogatásban nem részesült.

Szerzői munkamegosztás: E. M.: A vizsgálat tervezése, a közlemény megírása. K. I., Cs. B., R. M., E. M., R. Zs.: A vizsgálatok elvégzése. N. Z. Zs., K. I., R. Zs.: A közlemény kritikai revíziója. A cikk végleges változatát valamennyi szerző elolvasta és jóváhagyta.

Érdekeltségek: A szerzőknek nincsenek érdekeltségeik.

\section{Irodalom}

[1] Klein R, Klein BE, Linton KL. Prevalence of age-related maculopathy. The Beaver Dam Eye Study. Ophthalmology 1992; 99: 933-943.

[2] Ferris FL 3rd, Fine SL, Hyman L. Age-related macular degeneration and blindness due to neovascular maculopathy. Arch Ophthalmol. 1984; 102: 1640-1642.

[3] Fehér J, Kovács B, Kovács I, et al. Metabolic therapy for early treatment of age-related macular degeneration. [Metabolikus terápia az időskori makuladegeneráció korai kezelésére.] Orv Hetil. 2007; 148: 2259-2268. [Hungarian]

[4] Lakhanpal V. Experimental and clinical observations on massive suprachoroidal hemorrhage. Trans Am Ophthalmol Soc. 1993; 91: 545-652.

[5] Khawly JA, Ferrone PJ, Holck DE. Choroidal hemorrhage associated with systemic tissue plasminogen activator. Am J Ophthalmol. 1996; 121: 577-578.
[6] Winslow RL, Stevenson W 3rd, Yanoff M. Spontaneous expulsive choroidal hemorrhage. Arch Ophthalmol. 1974; 92: 33-36.

[7] Ophir A, Pikkel J, Groisman G. Spontaneous expulsive suprachoroidal hemorrhage. Cornea 2001; 20: 893-896.

[8] Garrott HM, Haynes RJ. Blindness from suprachoroidal haemorrhage in two patints with age-related macular degeneration on systemic anticoagulation therapy or an antiplatelet agent. Med J Aust. 2010; 192: 346-347.

[9] Ung T, James M, Gray RH. Long term warfarin associated with bilateral blindness in a patient with atrial fibrillation and macular degeneration. Heart 2003; 89: 985.

[10] Knox FA, Johnston PB. Spontaneous suprachoroidal haemorrhage in a patient with age-related macular degeneration on excessive anticoagulation therapy. Eye 2002; 16: 669-670.

[11] Alexandrakis G, Chaudhry NA, Liggett PE, et al. Spontaneous suprachoroidal hemorrhage in age-related macular degeneration presenting as angle-closure glaucoma. Retina 1998; 18: 485486.

[12] Edwards P. Massive choroidal hemorrhage in age-related macular degeneration: a complication of anticoagulant therapy. J Am Optom Assoc. 1996; 67: 223-226.

[13] Lewis H, Sloan SH, Foos RY. Massive intraocular hemorrhage associated with anticoagulation and age-related macular degeneration. Graefes Arch Clin Exp Ophthalmol. 1988; 226: 59-64.

[14] Chu TG, Green RL. Suprachoroidal hemorrhage. Surv Ophthalmol. 1999; 43: 471-486.

[15] Scott IU, Flynn HW Jr, Schiffmann J, et al. Visual acuity outcomes among patients with appositional suprachoroidal hemorrhage. Ophthalmology 1997; 104: 2039-2046.

[16] Lakhanpal V, Schocket SS, Elman MJ, et al. A new modified vitreoretinal surgical approach in the management of massive suprachoroidal hemorrhage. Ophthalmology 1989; 96: 793-800.

[17] Wong JS. Spontaneous suprachoroidal hemorrhage in a patient receiving low-molecular-weight heparin (fraxiparine) therapy. Aust N Z J Ophthalmol. 1999; 27: 433-434.

[18] Sun MT, Wood MK, Chan W, et al. Risk of intraocular bleeding with novel oral anticoagulants compared with warfarin. A systematic review and meta-analysis. JAMA Ophthalmol. 2017; 135: 864-870.

[19] Chatterjee S, Sardar P, Biondi-Zoccai G, et al. New oral anticoagulants and the risk of intracranial hemorrhage: traditional and Bayesian meta-aanlysis and mixed treatment comparison of randomized trials of new oral anticoagulants in atrial fibrillation. JAMA Neurol. 2013; 70: 1486-1490.

(Ecsedy Mónika dr., Budapest, Mária u. 39., 1085 e-mail: ecsedy@yahoo.co.uk)

\section{"Multa senem circumveniunt incommoda." (Horatius) (Sok baj kerülgeti az öreget.)}

A cikk a Creative Commons Attribution-NonCommercial 4.0 International License (https://creativecommons.org/licenses/by-nc/4.0) feltételei szerint publikált Open Access közlemény, melynek szellemében a cikk nem kereskedelmi célból bármilyen médiumban szabadon felhasználható, megosztható és újraközölhető, feltéve, hogy az eredeti szerző és a közlés helye, illetve a CC License linkje és az esetlegesen végrehajtott módositások feltüntetésre kerülnek. 